\title{
Cultural adaptation of Infant Feeding Intentions Scale (IFI) for pregnant women in Brazil
}

\author{
Adaptação cultural da Infant Feeding Intentions Scale (IFI) para gestantes no Brasil \\ Adaptación cultural de Infant Feeding Intentions Scale (IFI) para mujeres embarazadas en Brasil
}

Fernanda Garcia Bezerra Góes'
ORCID: 0000-0003-3894-3998

Beatriz Cabral Ledo'

ORCID: 0000-0002-2592-9364

Andressa Silva Torres dos Santos' ORCID: 0000-0001-7142-911X

Fernanda Maria Vieira Pereira-Ávila' ORCID: 0000-0003-1060-6754

Aline Cerqueira Santos Santana da Silva' ORCID: 0000-0002-8119-3945

Marialda Moreira Christoffel" ORCID: 0000-0002-4037-8759

'Universidade Federal Fluminense. Rio das Ostras, Rio de Janeiro, Brazil.

"Universidade Federal do Rio de Janeiro. Macaé, Rio de Janeiro, Brazil.

How to cite this article:

Góes FGB, Ledo BC, Santos AST, Pereira-Ávila FMV Silva ACSS, Christoffel MM. Cultural adaptation of Infant Feeding Intentions Scale (IFI) for pregnant women in Brazil.

Rev Bras Enferm. 2020;73(Suppl 4):e20190103. doi: http://dx.doi.org/10.1590/0034-7167-2019-0103

\section{Corresponding author:}

Fernanda Garcia Bezerra Góes

E-mail:ferbezerra@gmail.com

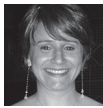

EDITOR IN CHIEF: Antonio José de Almeida Filho ASSOCIATE EDITOR: Mitzy Reichembach

Submission: 02-14-2019

Approval: 10-27-2019

\section{ABSTRACT}

Objectives: to translate and culturally adapt the Infant Feeding Intentions Scale for pregnant women in Brazil. Methods: methodological study that included stages of translation, synthesis, face and content validation, back translation and semantic assessment. In the face and content and semantic validation stages, we used the Content Validity Index for individual items and for the overall scale for clarity and representativeness. Results: nine (100.0\%) experts participated in face and content validation, and the average index obtained was $85.0 \%$ for representativeness. In the semantic assessment, performed with 31 (100.0\%) pregnant women, the tool was considered clear, obtaining an average index of $91.0 \%$. Conclusions: the Brazilian version of the scale was considered representative and clear. After assessing psychometric properties, the scale is expected to be valid and reliable to assess maternal intention to breastfeed exclusively until the infant's six months of life in different Brazilian settings.

Descriptors: Intention; Pregnant Women; Infant Nutrition; Validation Studies; Breastfeeding.

\section{RESUMO}

Objetivos: traduzir e adaptar culturalmente a Infant Feeding Intentions Scale para gestantes no Brasil. Métodos: estudo metodológico que incluiu etapas de tradução, síntese, validação de face e conteúdo, retrotradução e avaliação semântica. Nas etapas de validação de face e conteúdo e semântica, utilizou-se o Índice de Validade de Conteúdo para itens individuais e para a escala em geral quanto à clareza e à representatividade. Resultados: na validação de face e conteúdo participaram nove $(100,0 \%)$ especialistas, e o índice médio obtido foi de $85,0 \%$ para representatividade. Na avaliação semântica, realizada com 31 (100,0\%) gestantes, o instrumento foi considerado claro, obtendo-se índice médio de $91,0 \%$. Conclusões: a versão brasileira da escala foi considerada representativa e clara. Espera-se que após avaliação das propriedades psicométricas, a mesma seja válida e confiável, para avaliar a intenção materna de amamentar exclusivamente até os seis meses de vida do lactente em diferentes cenários brasileiros.

Descritores: Intenção; Gestantes; Nutrição Infantil; Estudos de Validação; Aleitamento Materno.

\section{RESUMEN}

Objetivos: traducir y adaptar culturalmente el Infant Feeding Intentions Scale para mujeres embarazadas en Brasil. Métodos: estudio metodológico que incluyó etapas de traducción síntesis, validación de cara y contenido, traducción inversa y evaluación semántica. En los pasos de validación semántica y de contenido, utilizamos el Índice de Validez de Contenido para elementos individuales y para la escala general para mayor claridad y representatividad. Resultados: nueve (100.0\%) expertos participaron en la validación facial y de contenido, y el promedio de índice obtenido fue de $85.0 \%$ para la representatividad. En la evaluación semántica, realizada con 31 (100.0\%) mujeres embarazadas, el instrumento se consideró claro, obteniendo un índice promedio de $91.0 \%$. Conclusiones: la versión brasileña de la escala se consideró representativa y clara. Después de evaluar las propiedades psicométricas, se espera que la misma sea válida y confiable para evaluar la intención materna de amamantar exclusivamente hasta los seis meses de vida del bebé en diferentes entornos brasileños. Descriptores: Intención; Mujeres Embarazadas; Nutrición del Lactante; Estudios de Validación; Lactancia Materna. 


\section{INTRODUCTION}

Breastfeeding is a natural strategy of bonding, affection, protection and nutrition for the child. It is the most sensitive, cost-effective and effective intervention to reduce child morbidity and mortality, especially caused by infectious diseases, and it has numerous short- and long-term health benefits for children and mothers ${ }^{(1)}$.

Among the benefits to the child, improvements in nutritional and immune status stand out. There is a reduction in the risk of obesity, type 2 diabetes and infections, as well as the bond between mother and child, as well as the positive impact on growth and cognitive and emotional development in childhood, which have significant repercussions for adulthood. Advantages to maternal health include accelerated postpartum weight loss, decreased risk of breast and ovarian cancer, as well as reduced risk of postpartum depression and osteoporosis during menopause ${ }^{(1-5)}$.

The World Health Organization (WHO), the American Academy of Pediatrics (AAP) and the Brazilian Ministry of Health (MoH) recommend the exclusive practice of breastfeeding up to six months of life, supplemented by two years and above ${ }^{(2,6-7)}$. However, despite the recommendations, in low and middle income countries, only $37 \%$ of children under six months are exclusively breastfed. It is emphasized that the duration of breastfeeding is even shorter in high income countries ${ }^{(2)}$.

In Brazil, studies on breastfeeding indicators in the last three decades indicated an upward trend, especially between 1986 and 2006. This was the period in which there was a significant increase in the prevalence of exclusive breastfeeding in children under six months, of $4.7 \%$. to $37.1 \%$ respectively. On the other hand, there was relative stabilization in 2013 , with a reduction of $0.3 \%$ of this type of breastfeeding among infants from zero to two months of age, and of $15.1 \%$ among those from three to five months of age ${ }^{(8)}$. However, it should be noted that the World Health Assembly set in 2012, as one of the global nutrition goals for 2025 , to increase the rate of exclusive breastfeeding to at least $50 \%{ }^{\left({ }^{(9)}\right.}$.

A meta-analysis of Brazilian epidemiological studies highlighted that maternal variables (under 20 years of age, low education, primiparity, postpartum maternal work and low family income) and neonatal variables (low birth weight, female sex, and pacifier use) are associated with interruption of breastfeeding until the child's sixth month of life. However, most of these factors can be modified through public policies, with actions aimed at promoting this practice, especially during prenatal care ${ }^{(10)}$.

The decision-making process of women about exclusive breastfeeding is a multidimensional phenomenon, as there are not only biological, but social, cultural and emotional challenges. Therefore, the intention to breastfeed is the result of a complex and progressively constructed behavior since the gestational period $^{(11)}$. Furthermore, studies indicate that there is a relationship between knowledge of benefits and personal beliefs, built on women's life trajectories, with the motivation to breastfeed ${ }^{(5,12)}$.

In this context, maternal intention to breastfeed is considered one of the most significant modifiable factors associated with this practice because the stronger the mother's intention to breastfeed, the more likely she is to breastfeed and for an extended period $^{(4,13-14)}$. This relationship can be explained by considering that the practice of breastfeeding is predetermined by intention, which is influenced by attitude, knowledge, exposure and perceived behavior ${ }^{(4,15)}$.

Therefore, the assessment of the intention and the factors that determine the mother's decisions regarding infant feeding is therefore crucial for the development of specific health education policies, programs and interventions for the promotion and prolongation of breastfeeding, having as its objective consequent reduction in early weaning ${ }^{(15-16)}$.

Based on the above, it is necessary to use valid and reliable tools that measure maternal intention to breastfeed, for use in clinical practice and research. The Infant Feeding Intentions Scale (IFI) consists precisely of a constructed and validated scale, both in English and Spanish, with Cronbach's alpha coefficient of 0.90. It was developed by Laurie Nommsen-Rivers and Kathryn Dewey in 2009 in a California hospital in the United States of America, among low-income primiparous women from different ethnic groups. The tool simply, quantitatively and reliably measures maternal intentions to start and continue exclusive breastfeeding until 1,3 or 6 months of the child's life or use of the formula ${ }^{(13)}$.

The answer options are based on a five-option Likert scale, individually scored from 0 to 4 , and the total score is calculated by averaging the score of the first two items plus items 3 to 5 . The score ranges from 0 to 16 , with 0 representing a very strong intention not to breastfeed and 16 representing a very strong intention to breastfeed as the sole source of milk until six months of age ${ }^{(4,13-14)}$.

Other tools based on behavioral theories, such as the Rational Choice Theory and the Transtheoretical Model, served as the basis for the development of the original IFI, such as the Manstead and Smart force of intent to initiate breastfeeding in 1983; and what assesses Humphreys, Thompson and Miner infant feeding plans in 1998 through five alternatives that represent different stages of changing behavior regarding breastfeeding, including pre-contemplation, contemplation, preparation, action and maintenance ${ }^{(13)}$. This last tool, which, in addition to these five items, has 20 statements that assess the processes of change for exclusive breastfeeding, was cross-culturally adapted in Brazil in $2016^{(17)}$.

However, IFI has made advances in these tools as it incorporates the two-dimensional nature of breastfeeding intent. In other words, this scale encompasses both strength and duration of intentions to exclusively breastfeed up to six months of age ${ }^{(13)}$. It has already been widely used in other international surveys measuring this construct in the US itself ${ }^{(5,14,18-19)}$ and in different countries such as Lebanon and Syria ${ }^{(15)}$, Australia ${ }^{(20)}$, Jordan ${ }^{(7)}$, Indonesia ${ }^{(21)}$ and Puerto Rico ${ }^{(5)}$. However, no studies regarding the Brazilian reality using the Infant Feeding Intentions Scale (IFI) were found, despite its internationally proven relevance.

\section{OBJECTIVES}

To translate and culturally adapt the Infant Feeding Intentions Scale (IFI) for pregnant women in Brazil.

\section{METHODS}

\section{Ethical aspects}

Authorization was granted by the creator of the original tool for cultural adaptation and scale validation. The Research Ethics 
Committee of Escola de Enfermagem Anna Nery at Universidade Federal do Rio de Janeiro approved the study, with CAAE (Certificado de Apresentação para Apreciação Ética - Certificate of Presentation for Ethical Consideration) 80711517.8.1001.5238 and Opinion 2.507.525, according to the recommendations of Resolution 466/2012 of the Brazilian National Health Board (Conselho Nacional de Saúde) ${ }^{(22)}$. All participants signed the Informed Consent Form (ICF). It should be noted that this study is linked to the multicenter project entitled "Aleitamento materno exclusivo: determinantes socioculturais no Brasil" (freely translated as Exclusive breastfeeding: sociocultural determinants in Brazil).

\section{Design, place of study and period}

This is a methodological study aimed at the translation and cultural adaptation of the Infant Feeding Intentions Scale (IFI). The methodological framework used was the one proposed by Beaton, Bombardier, Guillemin and Ferraz, respecting the following stages: initial translation, translation synthesis, face and content validation by the judges committee, back translation and semantic validation ${ }^{(23)}$. For the description of the research, the guidelines for observational studies were adopted (STROBE) (24).

The whole process of translation and cultural adaptation of the tool in question took place within one year. Initial translation and synthesis of translations took place from November 2017 to March 2018. Face and content validation took place via e-mail from March to April 2018. Back translation was performed in May 2018, while validation semantics, in three Family Health Strategy units in the city of Macaé, Rio de Janeiro, Brazil, from May to November 2018.

\section{Sample, and inclusion and exclusion criteria}

In the face and content validation phase of the tool, the committee of judges was composed of nine specialists, these five nurses, one doctor, one pregnant woman, one teacher of Portuguese language and one researcher of the method.

In the semantic validation stage, the sample consisted of 31 pregnant women, over 18 years old, who attended prenatal consultations in the Family Health Strategy units and agreed to participate in the research. Pregnant women with psychiatric and/or neurological problems and/or hearing impairment were excluded due to communication-related limitations, since no member of the research team dominated sign language, besides pregnant women who had clinical complications on the day of data collection. To this end, a previous survey was conducted with the health teams of the units of pregnant women who met the study criteria.

All pregnant women in the area covered by health units, regardless of gestational age and previous breastfeeding experiences, were potentially eligible to participate in the study, considering the inclusion and exclusion criteria. Maternal intention to breastfeed is a multidimensional phenomenon built throughout life. This process is mediated, for example, by biological, ethnic, cultural, socioeconomic, demographic and family factors, so it does not depend exclusively on previous experiences with breastfeeding practice ${ }^{(11)}$. It is noteworthy that the interest of the study was not to measure the intention to breastfeed in a specific group of pregnant women, but to culturally adapt the tool to a diverse sample.

\section{Study protocol}

The process of cultural adaptation was performed in order to produce semantic, idiomatic, cultural and conceptual equivalence between the original and the adapted tool, from the following stages $^{(23)}$ :

\section{Stages 1 and 2: initial translation and synthesis of translations}

Two certified translators with Spanish language skills and knowledge independently translated the tool from Spanish to Brazilian Portuguese. From the two translated versions, a synthesis was carried out, culminating in the elaboration of the first consensual version (version 1).

\section{Stage 3: review by a committee of judges}

Version 1 was assigned to the judges' committee for face and content validation. It was verified whether the analyzed scale is capable of accurately measuring the phenomenon to be studied. For this, two attributes were judged, the clarity, to verify the proper wording of the items. In other words, if they have been written coherently and concisely, so that the idea is understandable, and adequately expresses what one expects to measure; and representativeness, to assess whether the items reflect the concepts involved and whether they are relevant and appropriate to achieve the proposed objectives ${ }^{(25)}$.

Implementation of the assessment by the committee, soon after the first consensus version has been established, is a recommended strategy to avoid translation errors at the back translation stage $^{(26)}$. The judges received the original Spanish version of the scale, the first consensual version, the explanatory script attached to the assessment tool and the IC via e-mail. The semantic, idiomatic, cultural and conceptual equivalences ${ }^{(23)}$ were assessed and, after this phase, the second consensual version (version 2) of the back-translation tool was established.

\section{Stage 4: back translation}

Version 2 has been back-translated into the original languages, Spanish and English, in order to verify the quality between the original and the translated versions. It is noteworthy that backtranslation into English was also necessary as the original scale was constructed in both languages. The versions were sent to the original author for consideration and review, obtaining their approval without change.

\section{Stage 5: target audience validation}

In the semantic validation stage, it was verified the quality of the translation and the comprehension of the items, version 2 , of the scale by the pregnant women (target audience), as to the meaning of the words and interpretation of the utterances. 
Data were collected through the interview technique, using the following tools: a) socioeconomic characterization form and clinical aspects of pregnancy and; b) IFI version 2 semantic analysis questionnaire. The number of participants in this stage was in line with the recommendations in the literature (minimum 30 to 40 subjects) ${ }^{(23)}$.

\section{Analysis of results and statistics}

Data were typed, organized and analyzed using Microsoft Excel $^{\circ} 2016$ software. Aiming to characterize the group studied, descriptive analyzes of simple frequency (categorical variables), central tendency (mean and median) and dispersion (standard deviation) were performed.

In the stages of face and content validation and semantics we used the Content Validity Index (CVI) for each item and for the scale in general. The aim was to analyze the degree of agreement between the judges and the pregnant women regarding the clarity and representativeness of the IFI, with answers obtained by a Likert scale and a score ranging from one to four ${ }^{(25)}$.

CVI was calculated from the sum of the answers classified as three and four, divided by the total number of answers. Answers 3 and 4 include those considered clear and very clear or representative and very representative. A minimum index of 0.78 was considered acceptable, both for the assessment of each item and for the tool's overall assessment, because according to the literature recommendation, it is necessary to consider the number of judges to determine the agreement rate between them. In studies with six or more raters, a rate of not less than $78 \%$ is recommended ${ }^{(25)}$.

\section{RESULTS}

IFI was translated by two certified translators, assessed for content, especially for its clarity and representativeness by judges and pregnant women and back-translated into the source languages.

Regarding face and content validity, the committee agreed on the items and the scale in general, ensuring their semantic, idiomatic, cultural and conceptual equivalence. Thus, IFI version 1 items have undergone few modifications related to the written form. All changes made as well as the suggested suggestions are shown in Chart 1.

When assessed separately by the judges, the items on the scale were considered representative or very representative, ranging from $0.78(78.0 \%)$ to $0.89(89.0 \%)$ (Table 1$)$. In the analysis of the global average CVI of the scale, 0.85 (85.0\%).

By the suggestions proposed by the judges regarding version 1 of the tool, the most recurrent ones were listed. Thus, the word "fórmula" has been replaced by one of simple language with the same semantic meaning, in this case, "leite artificial", and the term "ao seio" has been added after "amamentação". Changes were carried out to the scale statement replacing "vou ler para você" for "as frases abaixo são sobre a amamentação do seu bebê".

After this phase, back translation of the consensual version of the scale (version 2) was then performed, with its subsequent referral to the original author and respective approval, considering that there were no suggestions for alteration.

Chart 1 - Comparison of the original Spanish version, the translations, the synthesis of the translations and the final Brazilian Portuguese version, Macaé, Rio de Janeiro, Brazil, 2018

\begin{tabular}{|c|c|c|c|c|c|}
\hline Items & $\begin{array}{l}\text { Original } \\
\text { Spanish } \\
\text { version }\end{array}$ & Translation 1 & Translation 2 & $\begin{array}{l}\text { Synthesis of } \\
\text { translations } \\
\text { (version 1) }\end{array}$ & $\begin{array}{l}\text { Brazilian } \\
\text { version of } \\
\text { scale }\end{array}$ \\
\hline 1 & $\begin{array}{l}\text { 1. Tengo } \\
\text { planes de sólo } \\
\text { alimentarle } \\
\text { fórmula a mi } \\
\text { bebé (no voy a } \\
\text { amamantar) }\end{array}$ & $\begin{array}{l}\text { 1. Pretendo } \\
\text { alimentar meu bebê } \\
\text { apenas com } \\
\text { fórmulas } \\
\text { [infantis] (não vou } \\
\text { amamentar) }\end{array}$ & $\begin{array}{l}\text { 1. Tenho planos } \\
\text { de só alimentar } \\
\text { o meu bebê com } \\
\text { fórmula (não vou } \\
\text { amamentar) }\end{array}$ & $\begin{array}{l}\text { 1. Tenho planos } \\
\text { de só alimentar } \\
\text { o meu bebê com } \\
\text { fórmula (não vou } \\
\text { amamentar) }\end{array}$ & $\begin{array}{l}\text { 1. Tenho planos } \\
\text { de somente } \\
\text { alimentar o meu } \\
\text { bebê com leite } \\
\text { artificial (não vou } \\
\text { amamentar ao } \\
\text { seio) }\end{array}$ \\
\hline 2 & $\begin{array}{l}\text { 2. Tengo planes } \\
\text { depor los menos } \\
\text { intentar a } \\
\text { amamantar }\end{array}$ & $\begin{array}{l}\text { 2. Pretendo } \\
\text { amamentar meu } \\
\text { bebê ou, pelo } \\
\text { menos, tentar }\end{array}$ & $\begin{array}{l}\text { 2. Tenho planos de } \\
\text { amamentar o meu } \\
\text { bebê ou pelo menos } \\
\text { tentar }\end{array}$ & $\begin{array}{l}\text { 2. Tenho } \\
\text { planos de pelo } \\
\text { menos tentar } \\
\text { amamentar }\end{array}$ & $\begin{array}{l}\text { 2. Tenho } \\
\text { planos de pelo } \\
\text { menos tentar } \\
\text { amamentar } \\
\text { ao seio }\end{array}$ \\
\hline 3 & $\begin{array}{l}\text { 3. Cuando mi } \\
\text { bebé tenga } \\
\text { un mes, le } \\
\text { amamantarésin } \\
\text { usar ninguna } \\
\text { fórmula infantil } \\
\text { ni otra leche }\end{array}$ & $\begin{array}{l}\text { 3. Quando meu } \\
\text { bebê tiver um mês } \\
\text { de vida, vou } \\
\text { amamentá-lo sem } \\
\text { usar nenhuma } \\
\text { fórmula infantil } \\
\text { nem outro leite }\end{array}$ & $\begin{array}{l}\text { 3. Quando meu/ } \\
\text { minha } \\
\text { bebê tiver um mês de } \\
\text { nascido/a, vou } \\
\text { amamentá-lo/la } \\
\text { sem } \\
\text { usar nenhuma } \\
\text { fórmula infantil nem } \\
\text { outro leite }\end{array}$ & $\begin{array}{l}\text { 3. Quando meu } \\
\text { bebê tiver um } \\
\text { mês de vida, } \\
\text { vou amamentá- } \\
\text { lo sem usar } \\
\text { nenhuma fórmula } \\
\text { nem outro leite }\end{array}$ & $\begin{array}{l}\text { 3. Quando meu } \\
\text { bebê tiver um } \\
\text { mês de vida, vou } \\
\text { amamentá-lo } \\
\text { somente ao seio } \\
\text { sem usar nenhum } \\
\text { outro leite } \\
\text { artificial }\end{array}$ \\
\hline 4 & $\begin{array}{l}\text { 3. Cuando mi } \\
\text { bebé tenga } \\
3 \text { mes, le } \\
\text { amamantarésin } \\
\text { usar ninguna } \\
\text { fórmula infantil } \\
\text { ni otra leche }\end{array}$ & $\begin{array}{l}\text { 4. Quando meu } \\
\text { bebê tiver } 3 \text { meses } \\
\text { de vida, vou } \\
\text { amamentá-lo sem } \\
\text { usar nenhuma } \\
\text { fórmula infantil } \\
\text { nem outro leite }\end{array}$ & $\begin{array}{l}\text { 4. Quando meu/ } \\
\text { minha } \\
\text { bebê tiver } 3 \text { meses de } \\
\text { nascido/a, vou } \\
\text { amamentá-lo/la } \\
\text { sem } \\
\text { usar nenhuma } \\
\text { fórmula infantil nem } \\
\text { outro leite }\end{array}$ & $\begin{array}{l}\text { 4. Quando meu } \\
\text { bebê tiver } 3 \\
\text { meses de vida, } \\
\text { vou amamentá- } \\
\text { lo sem usar } \\
\text { nenhuma fórmula } \\
\text { nem outro leite }\end{array}$ & $\begin{array}{l}\text { 4. Quando meu } \\
\text { bebê tiver três } \\
\text { meses de vida, } \\
\text { vou } \\
\text { amamentá-lo } \\
\text { somente ao seio } \\
\text { sem usar nenhum } \\
\text { outro leite } \\
\text { artificial }\end{array}$ \\
\hline 5 & $\begin{array}{l}\text { 3. Cuando mi } \\
\text { bebé tenga } \\
6 \text { mes, le } \\
\text { amamantarésin } \\
\text { usar ninguna } \\
\text { fórmula infantil } \\
\text { ni otra leche }\end{array}$ & $\begin{array}{l}\text { 5. Quando meu } \\
\text { bebê tiver } 6 \text { meses } \\
\text { de vida, vou } \\
\text { amamentá-lo sem } \\
\text { usar nenhuma } \\
\text { fórmula infantil } \\
\text { nem outro leite }\end{array}$ & $\begin{array}{l}\text { 5. Quando meu/ } \\
\text { minha } \\
\text { bebê tive } 6 \text { meses de } \\
\text { nascido/a, vou } \\
\text { amamentá-lo/la } \\
\text { sem } \\
\text { usar nenhuma } \\
\text { fórmula infantil nem } \\
\text { outro leite }\end{array}$ & $\begin{array}{l}\text { 5. Quando meu } \\
\text { bebê tiver } 6 \\
\text { meses de vida, } \\
\text { vou amamentá- } \\
\text { lo sem usar } \\
\text { nenhuma fórmula } \\
\text { nem outro leite }\end{array}$ & $\begin{array}{l}\text { 5. Quando meu } \\
\text { bebê tiver seis } \\
\text { meses de vida, } \\
\text { vou } \\
\text { amamentá-lo } \\
\text { somente ao seio } \\
\text { sem usar nenhum } \\
\text { outro leite } \\
\text { artificial }\end{array}$ \\
\hline
\end{tabular}


Table 1 - Content Validity Index Results by expert judges, Macaé, Rio de Janeiro, Brazil, 2018

\begin{tabular}{cccc}
\hline Item & $\begin{array}{c}\text { Not representative/ } \\
\text { little representative }\end{array}$ & $\begin{array}{c}\text { Representative/very } \\
\text { representative }\end{array}$ & $\begin{array}{c}\text { Content } \\
\text { Validity Index }\end{array}$ \\
\hline Item 1 & 2 & 7 & 0.78 \\
Item 2 & 1 & 8 & 0.89 \\
Item 3 & 2 & 7 & 0.78 \\
Item 4 & 1 & 8 & 0.89 \\
Item 5 & 1 & 8 & 0.89 \\
\hline
\end{tabular}

Table 2 - Sociodemographic characterization of pregnant women, in the semantic validation phase, Macaé, Rio de Janeiro, Brazil, 2018

\begin{tabular}{|c|c|c|}
\hline & $\mathbf{n}$ & $\%$ \\
\hline \multicolumn{3}{|l|}{ Schooling } \\
\hline Incomplete elementary school & 04 & 12.9 \\
\hline Complete elementary school & 03 & 9.7 \\
\hline Incomplete high school & 10 & 32.3 \\
\hline Complete high school & 13 & 41.9 \\
\hline Incomplete higher education & 01 & 3.2 \\
\hline \multicolumn{3}{|l|}{ Family income* } \\
\hline No income & 01 & 3.2 \\
\hline Up to 1 minimum wage & 08 & 25.8 \\
\hline $1-2$ minimum wages & 13 & 41.9 \\
\hline From 2-3 minimum wages & 04 & 12.9 \\
\hline 3-4 minimum wages & 02 & 6.5 \\
\hline \multicolumn{3}{|l|}{ Housing Type } \\
\hline Masonry & 31 & 100.0 \\
\hline \multicolumn{3}{|l|}{ Number of people residing at home } \\
\hline 1-3 people & 19 & 61.3 \\
\hline From 4-6 people & 11 & 35.5 \\
\hline Over 7 & 01 & 3.2 \\
\hline \multicolumn{3}{|l|}{ Legal drug use* } \\
\hline Alcohol & 06 & 19.4 \\
\hline Tobacco & 02 & 6.5 \\
\hline \multicolumn{3}{|l|}{ Religion* } \\
\hline Evangelical & 15 & 48.4 \\
\hline Catholic & 04 & 12.9 \\
\hline None & 09 & 29.0 \\
\hline \multicolumn{3}{|l|}{ Gestational Age* } \\
\hline Up to 22 weeks & 08 & 25.8 \\
\hline From 23-36 weeks & 12 & 38.7 \\
\hline Over 37 weeks & 04 & 12.9 \\
\hline \multicolumn{3}{|l|}{ Previous gestation } \\
\hline Yes & 25 & 80.6 \\
\hline No & 06 & 19.4 \\
\hline
\end{tabular}

Table 3 - Results of Content Validity Indexes for semantic validity by pregnant women, Rio das Ostras, Rio de Janeiro, Brazil, 2018

\begin{tabular}{cccc}
\hline Item & $\begin{array}{c}\text { Unclear/ } \\
\text { little clear }\end{array}$ & $\begin{array}{c}\text { Clear/ } \\
\text { very clear }\end{array}$ & $\begin{array}{c}\text { Content Validity } \\
\text { Index }\end{array}$ \\
\hline Item 1 & 3 & 28 & 0.90 \\
Item 2 & 1 & 30 & 0.96 \\
Item 3 & 1 & 30 & 0.96 \\
Item 4 & 2 & 29 & 0.93 \\
Item 5 & 6 & 25 & 0.80 \\
\hline
\end{tabular}

In the semantic validation phase, performed with 31 (100.0\%) pregnant women, the average age was 25.2 years $(S D=5.46)$, with a minimum age of 18 and a maximum of 35 years. Of this sample, the majority, 13 (41.9\%), had completed high school (Table 2).

From the total of pregnant women who participated, 24 (77.4\%) could tell exactly the weeks corresponding to their gestational age $(G A)$, with a mean of 23.6 weeks $(S D=10.7)$, with a minimum of 6 weeks and maximum of 39 .

According to Table 2, 25 (80.6\%) of the pregnant women had previous pregnancies, of which $23(92.0 \%)$ breastfed their children, showing variation regarding the period. The minimum found was one month and the maximum four years and six months. In this context, the percentage of early weaning found was $38.7 \%$.

From the analysis of IFI version 2 , the items individually assessed, as well as the tool as a whole, were considered acceptable regarding clarity (Table 3 ). Individually, CVI ranged from 0.80 (80.0\%) to $0.96(96.0 \%)$ and the overall mean CVI was 0.91 (91.0\%).

As there were no changes in the consensus version 2 after the assessment by pregnant women, it is configured in the Brazilian version of the IFI.

\section{DISCUSSION}

The cultural adaptation of the IFI was carried out systematically and followed all the recommended stages. The rigor in the process of adapting a previously existing measuring tool ensures quality to the adapted tool ${ }^{(23)}$.

Thus, despite being a complex process, one must consider the linguistic and cultural aspects, aiming at the quality of the adapted tool, in order to adapt it to different populations. Therefore, the validation of tools is a fundamental aspect to make them complete, with greater scientific rigor and to guarantee their legitimacy, credibility and reliability, so that they are able to measure what is proposed ${ }^{(27)}$.

Carrying out this process in this study stems from the need for a standardized tool that can safely measure maternal intention to breastfeed, exclusively in the Brazilian context, similar to international studies conducted in several countries, in which this construct was validated ${ }^{(4,7,14-15,20-21)}$.

In Brazil, the face and content validation stage, which had a committee of judges, followed the recommendations. It was considered that the composition of the committee should be five to ten expert judges in the area of the tool ${ }^{(28)}$, including at least methodologist, health professional and linguistic professional ${ }^{(23)}$. The participation of a member of the target population to whom the tool is intended is also recommended ${ }^{(29)}$, as performed in the study. This committee provided feedback on the comprehensibility of the issues, so their contributions were essential in making the material clearer and more appropriate for the intended audience.

From the judges' perspective, the IFI was considered representative, since it reached CVI from 78\%, as recommended by the literature ${ }^{(25)}$. They assessed the scale and its items as adequate and relevant to achieve the objective proposed by the tool.

Through the assessment of semantic, idiomatic, cultural and conceptual equivalences it was identified that between the original tool and its Brazilian version some items presented a greater divergence regarding semantic and idiomatic equivalence. Thus, some words were modified or added in order to improve the clarity of the tool and consequently facilitate the understanding of pregnant women. Studies point out that for an adequate translation, the analysis of such concepts is fundamental so that the terms used in the tool are coherent with the reality of the target population, within their cultural context, and are subject to modification when presented in opposite ways ${ }^{(23)}$. 
In this aspect, the orientation described at the beginning of the scale induced the conduction of an interview, so changes were made in the statement aiming to obtain the same meaning either for its use through an interview or in a self-applicable way.

In addition to expert validation, it is a critical attitude for the study to validate the material with audience representatives, as it is the moment to see what is really missing, what is not appropriate, and how information is understood ${ }^{(30)}$.

The sample used in the semantic validation stage and the percentage used, considering education level, is consistent with the literature recommendation ${ }^{(31)}$, which increases the representativeness of the sample. A good level of education allows better maternal assimilation of information received, while the less educated population may be more susceptible to misinterpretation of concepts ${ }^{(11,32)}$. This reinforces the importance of participants with different levels of education in studies of this nature.

Early weaning in Brazil, even evidenced among pregnant women in this study, is a serious public health problem. This requires health professionals, especially nurses in family health units, targeted and qualified assistance for the recognition of the intervening factors in the decision to breastfeed ${ }^{(33)}$. That said, it reinforces the need to use scales such as the IFI, which quantitatively measure maternal intentions to breastfeed and predict exclusive breastfeeding ${ }^{(4)}$, being a starting point for investigating these factors.

The analysis performed with pregnant women regarding clarity also obtained acceptable CVI, that is, the items are adequately described, were written coherently and concisely and so that the idea is understandable.

Therefore, it is necessary to assess the psychometric properties of the Brazilian version of the IFI. In other research examining the validity of the original IFI construct in an intra-ethnic group and the comparability between ethnic groups in a triple sample (African American, Hispanic, and non-Hispanic white women), Cronbach's alpha variation was 0,70 to 0.85 for initiation factor and 0.90 to 0.93 for breastfeeding continuation factor ${ }^{(14)}$. In the study that validated an Arabic version of the Lebanese women scale, the reliability of Cronbach's alpha internal consistency was $0.82^{(4)}$. Therefore, IFl's English, Spanish and Arabic versions have good levels of internal consistency.

\section{Study limitations}

As a limitation of the study, it is emphasized that the adaptation process of a measuring tool may be influenced by the context and characteristics of the population, so its psychometric properties need to be tested.

\section{Contributions to nursing}

The study is expected to contribute to the nursing field. The scale can be used as a tool by nurses during prenatal care to measure maternal intention to breastfeed and consequently identify possible barriers to exclusive breastfeeding that may lead to early weaning. Thus, it will be possible to establish an individualized care plan for pregnant women, aiming to motivate them for this practice, through educational interventions appropriate to each life context, making it possible to reduce the early weaning rate.

\section{CONCLUSIONS}

Upon completion of the cultural adaptation process of the Brazilian version of the IFI, semantic, idiomatic, cultural and conceptual equivalences were obtained between the translated version and the original version. The tool was assessed as clear and representative, based on the stages recommended by the literature. Therefore, the Brazilian version of IFI for pregnant women is culturally adapted to Brazil.

After assessing psychometric properties, the scale is expected to be valid and reliable to assess maternal intention to breastfeed exclusively until the infant's six months of life in different Brazilian settings.

\section{FUNDING}

This study was funded by the Rio de Janeiro State Research Support Foundation (FAPERJ - Fundação de Amparo à Pesquisa do Estado de Rio de Janeiro) through the scientific initiation scholarship.

\section{REFERENCES}

1. Victora CG, Horta BL, Mola CL, Quevedo L, Pinheiro RT, Gigante DP, et al. Association between breastfeeding and intelligence, educational attainment, and income at 30 years of age: a prospective birth cohort study from Brazil. Lancet Global Health. 2015;3:e199-205. doi: $10.1016 /$ S2214-109X(15)70002-1

2. Victora CG, Bahl R, Barros AJD, França GVA, Hoton S, Krasevec J et al. Breastfeeding in the 21st century: epidemiology, mechanisms, and lifelong effect. Lancet. 2016;387(10017):475-90. doi: 10.1016/S0140-6736(15)01024-7

3. Toryiama AUM, Fujimori E, Palombo CNT, Duarte LS, Borges ALV, Chofakian CBN. Lactancia materna: ¿qué ha cambiado en la última década? Rev Latino-Am Enfermagem. 2017;25:e2941. doi: 10.1590/1518-8345.1858.2941

4. Yehya N, Tamim H, Shamsedine L, Ayash S, Abdel Khalek L, Abou Ezzi A, et al. Validation of the Arabic Version of the Infant Feeding Intentions Scale Among Lebanese Women. J Hum Lactat. 2017;33(2):383-389. doi: 10.1177/0890334416680790

5. Parry KC, Tully KP, Hopper LN, Schildkamp PE, Labbok MH. Evaluation of Ready, Set, BABY: A prenatal breastfeeding. Birth. 2018;1-8. doi: 10.1111/ birt.12393

6. Ministério da Saúde (BR). Secretaria de Atenção à Saúde. Departamento de Atenção Básica. Saúde da criança: aleitamento materno e alimentação complementar. 2.ed. Brasília: Ministério da Saúde; 2015.

7. Al-Sagarat AY, Yaghmour G, Moxham L. Intentions and barriers toward breastfeeding among Jordanian mothers: a cross sectional 
descriptive study using quantitative method. Women Birth. 2017;30(4):e152-e157. doi: 10.1016/j.wombi.2016.11.001

8. Boccolini CS, Boccolini PMM, Monteiro FR, Venâncio SI, Giugliani ERJ. Breastfeeding indicators trends in Brazil for three decades. Rev Saúde Publica. 2017; 51:108. doi: 10.11606/s1518-8787.2017051000029

9. World Health Organization. Guideline: protecting, promoting and supporting breastfeeding in facilities providing maternity and newborn services. Geneva: World Health Organization; 2017.

10. Pereira-Santos M, Santana MS, Oliveira DS, Nepomuceno Filho RA, Lisboa CS, Almeida LMR, et al. Prevalence and associated factors for early interruption of exclusive breastfeeding: meta-analysis on Brazilian epidemiological studies. Rev Bras Saúde Matern Infantil. 2017;17(1):6978. doi: 10.1590/1806-93042017000100004

11. Vieira TO, Martins CC, Santana GS, Vieira GO, Silva LR. Intenção materna de amamentar: revisão sistemática. Rev Ciênc Saúde Coletiva. 2016;21(12):3845-58. doi: 10.1590/1413-812320152112.17962015

12. Rocha ALA, Góes FGB, Pereira FMV, Moraes JRMM, Barcia LLC, Silva LF. O processo de ensino-aprendizagem de puérperas nutrizes sobre aleitamento materno. Rev Cuidarte. 2018;9(2):2165-76. doi: 10.15649/cuidarte.v9i2.510

13. Nommsen-Rivers LA, Dewey KG. Development and validation of the infant feeding intentions scale. Matern Child Healh J. 2009;13(3):334-42. doi: 10.1007/s10995-008-0356-y

14. Nommsen-Rivers LA, Cohen RJ, Chantry CJ, Dewey KG. The Infant Feeding Intentions scale demonstrates construct validity and comparability in quantifying maternal breastfeeding intentions across multiple ethnic groups. Matern Child Nutrit. 2010;6(3):220-7. doi: 10.1111/j.1740-8709.2009.00213.x

15. Hamade H, Naja F, Keyrouz S, Hwalla N, Karam J, Al-Rustom L, Nasreddine L. Breastfeeding knowledge, attitude, perceived behavior, and intention among female undergraduate university students in the Middle East: the case of Lebanon and Syria. Food Nutrit Bull. 2014;35(2):179-90. doi: 10.1177/156482651403500204

16. Silva AE, Campos COM, Oliveira MCF, Ribeiro AQ, Cotta RMM, Araújo RMA. Changes in maternal conception about breastfeeding. Rev Bras Saúde Matern Infantil. 2016;16(4):407-14. doi: 10.1590/1806-93042016000400003

17. Campos COM, Silva AE, Oliveira MCF, Ribeiro AQ, Cotta RMM, Araújo RMA. Adaptação transcultural dos estágios de mudança de comportamento e processos de mudança para a amamentação exclusiva. Rev Nutrição. 2016;29(5):731-740. doi: $10.1590 / 1678-98652016000500011$

18. Chantry CJ, Dewey, KG., Peerson JM, Wagner EA, Nommsen-Rivers LA. In-hospital formula use increases early breastfeeding cessation among first-time mothers intending to exclusively breastfeed. J Pediatr. 2014;164(6):1339-45. doi: 10.1016/j.jpeds.2013.12.035

19. Linares AM, Rayens MK, Dozier A, Wiggins A, Dignan MB. Factors influencing exclusive breastfeeding at 4 months postpartum in a sample of urban Hispanic mothers in Kentucky. J Hum Lactat. 2015;31(2): 307-314. doi: 10.1177/0890334414565711

20. Jersey SJ, Mallan K, Forster J, Daniels LA. A prospective study of breastfeeding intentions of healthy weight and overweight women as predictors of breastfeeding outcomes. Midwife. 2017;53:20-27. doi: 10.1016/j.midw.2017.07.002

21. Permatasari TAE, Sartika RAD, Irawati EA, Ocviyanti D. Exclusive breastfeeding intention among pregmant women. Kesmas: Nation. J Public Health. 2018;12(3):134-141. doi: 10.21109/kesmas.v12i3.14466

22. Ministério da Saúde (BR). Resolução n. 466/2012. Diretrizes e Normas Regulamentadoras de Pesquisa Envolvendo Seres Humanos. Brasília: Conselho Nacional de Saúde; 2012.

23. Beaton DE, Bombardier C, Guillemin F, Ferraz MB. Guidelines for the process of crosscultural adaptation of self-report measures. Spine [Internet]. 2000 [cited 2019 Feb 12];(25):3186-91. Available from: https://www.ncbi.nlm.nih.gov/pubmed/11124735

24. Von Elm E, Altman DG, Egger M, Pocock SJ, Gotzsche PC, Vandenbroucke JP. The Strengthening the Reporting of Observational Studies in Epidemiology (STROBE) Statement: guidelines for reporting observational studies. Ann Intern Med. 2007;147(8):573-7. doi: 10.7326/0003-4819-147-8-200710160-00010

25. Alexandre NMC, Coluci MZO. Validade de conteúdo nos processos de construção e adaptação de instrumentos de medidas. Rev Ciênc Saúde Coletiva. 2011;16(7):3061-8. doi: 10.1590/S1413-81232011000800006

26. Ferrer M, Alonso J, Prieto L, Plaza V, Monsó E, Marrades R, et al. Validity and reliability of the St George's Respiratory Questionnaire after adaptation to a different language and culture: the Spanish example. European Respir J. 1996;9(6):1160-1166. doi: $10.1183 / 09031936.96 .09061160$

27. Medeiros RKS, Ferreira Jr MA, Pinto DPSR, Vitor AF, Santos VEP, Barichello E. Modelo de validação de conteúdo de Pasquali nas pesquisas em Enfermagem. Rev Enferm Ref. 2015;serIV(4):127-35. doi: 10.12707/RIV14009

28. Coluci MZO, Alexandre NMC, Milani D. Construção de instrumentos de medida na área da saúde. Rev Ciênc Saúde Coletiva. 2015;20(3):92636. doi: 10.1590/1413-81232015203.04332013

29. Ferreira L, Neves NA, Campana MB, Tavares MCGCF. Guia da AAOS/IWH: sugestões para adaptação transcultural de escalas. Rev Avaliaç Psicol [Internet]. 2014 [cited 2018 Mar 15];13(3):457-61. Available from: http://pepsic.bvsalud.org/scielo. php?script=sci_arttext\&pid=S1677-04712014000300018\&lng=pt\&nrm=i\&tlng=pt

30. Lima ACMACC, Bezerra KC, Sousa DMN, Rocha JF, Oriá MOB. Development and validation of a booklet for prevention of vertical HIV transmission. Acta Paul Enferm. 2017;30(2):181-9. doi: 10.1590/1982-0194201700028 
31. Deon KC, Santos DMSS, Reis RA, Fegadolli C, Bullinger M, Santos CB. Tradución y adaptación cultural para Brasil del Disabkids ${ }^{\circledR}$ Atopic Dermatitis Module (ADM). Rev Esc Enferm USP. 2011;45(2):450-7. doi: 10.1590/S0080-62342011000200021

32. Moura AF, Masquio DCL. A influência da escolaridade na percepção sobre alimentos considerados saudáveis. Rev Educ Pop [Internet]. 2014 [cited 2019 Jan 10];13(1):82-94. Available from: https://docplayer.com.br/24954619-A-influencia-da-escolaridade-na-percepcao-sobrealimentos-considerados-saudaveis.html

33. Alencar AP, Nascimento G, Lira P, Fonseca F, Fonseca R, Alves B, et al. Principais causas do desmame precoce em uma estratégia de saúde da família. Saúde Meio Amb: Rev Interdiscip. 2017;6(2),65-76. doi: 10.24302/sma.v6i2.1456 